\title{
Interactions between calcium phosphate and heavy metal ions in aqueous solution
}

\author{
F. Fernane, S. Boudia and H. Saouli \\ Laboratory of Applied Chemistry and Chemical Engineering (LCAGC), UMMTO, Algeria
}

\begin{abstract}
Synthetic and natural calcium phosphates were tested for removal metallic pollution in aqueous solution. Calcium phosphates with $\mathrm{Ca} / \mathrm{P}$ ratio between 1,33 and 1,67 are fluently called apatite. They have a strong capacity to immobilize metallic ions when they are brought into contact with aqueous solutions. $\mathrm{Ca}^{2+}$ ions can substituted completely or partly by cations such as metallic ions $\left(\mathrm{Ni}^{2+} ; \mathrm{Cu}^{2+} ; \mathrm{Co}^{2+}\right.$ and $\left.\mathrm{Cd}^{2+}\right)$. $\mathrm{PO}_{4}^{3-}$ ions can be replaced by anions such as $\mathrm{AsO}_{4}^{3-}, \mathrm{CO}_{3}^{2-}$, ... etc. Sorption of $\mathrm{Cu}^{2+}$ and $\mathrm{Ni}^{2+}$ from aqueous solutions on natural (NA) and synthetic (SA) apatite was investigated in batch mode at $25^{\circ} \mathrm{C}$ and $40^{\circ} \mathrm{C}$ and over metal concentration range of $20-800 \mathrm{mg} / \mathrm{L}$. Other experiments of co-precipitation metal-apatite (metalTCP) were investigated in static mode at $25^{\circ} \mathrm{C}$. The results characterization of NA and SA apatite by FTIR, SEM, and ICP confirm their composition and apatitic structure. The results confirm efficiency of these calcium phosphates to decontaminate, by adsorption or co-precipitation, metallic ions such as $\mathrm{Ni}^{2+}$ or $\mathrm{Cu}^{2+}$ present in aqueous solution at concentrations between $20-800 \mathrm{mg} / \mathrm{L}$.
\end{abstract}

\section{INTRODUCTION}

Several solid sorbents have been proposed for decontamination of industrial liquid wastes from toxic or radioactive elements. The use of mineral materials such as apatite showed big efficiency for decontamination of industrial waste [1-6]. Apatite is the name given to a group of crystals of the general chemical formula $\mathrm{M}_{10}\left(\mathrm{RO}_{4}\right) \mathrm{X}_{2}$, where $\mathrm{R}$ is most generally phosphorus, $\mathrm{M}$ could be one of the several metals, although it is usually calcium, and $\mathrm{X}$ is frequently hydroxide or a halogen such as fluorine or chlorine [7]. One of the most common apatite is calcium hydroxy apatite (Hap), whose theoretical formula is $\mathrm{Ca}_{10}$ $\left(\mathrm{PO}_{4}\right)_{6}(\mathrm{OH})_{2}$. Non stoichiometric Hap constitutes the mineral component of hard tissues (bone, dental enamel, etc.) of mammals [6-10].

Study interaction between metal ions such as cadmium, zinc, copper and nickel with apatite is of most interest both for the development of decontamination methods for liquid wastes and for the investigation of processes in human and animal hard tissues [12-14].

The retention mechanisms of heavy metal on apatite include ion exchange with diffusion into the sample, or precipitation of new solid phases, depending on the conditions and the reactivity of the substituted Hap [4-8].

Synthetic and natural phosphates of calcium were tested for reduction metallic pollution in aqueous solution. Sorption experiments of $\mathrm{Ni}^{2+}$ and $\mathrm{Cu}^{2+}$ ions such as on apatite were led in batch mode and in aqueous solution. Several operating parameters were studied such as $\mathrm{pH}$ ( $\mathrm{pH} 4$ and $\mathrm{pH} 5$ ), initial concentration of metallic solution (20 to $800 \mathrm{mg} / \mathrm{L})$, and temperature $\left(25\right.$ and $40^{\circ} \mathrm{C}$ ). Other experimentswere performed by dissolution - precipitation (co precipitation) of apatite with solution of $\mathrm{Ni}^{2+}$ ions at $25^{\circ} \mathrm{C}$ and $\mathrm{pH} 7$.

\section{EXPERIMENTAL}

\subsection{Materials and methods}

The natural apatite (NA) originated from a variety of human teeth, having undergoneadequate treatment. After treatment, teeth were calcined at $800^{\circ} \mathrm{C}$ for two hours then grounded in a mortar and sieved. The sample of 25 and $250 \mu \mathrm{m}$ size was collected and used for sorption experiments. The synthetic apatite (SA) was Bio-Rad ${ }^{\circledR}$ calcium phosphate (Bio-Rad ${ }^{\circledR}$ ) which was referenced DNA Grade Bio-Gel HTP 130-0420. Chemical composition of the starting apatite particles was determined by inductively coupled plasma atomic emission spectrometry (ICP/AES), with a Varian Vista spectrometer. The specific surface area was evaluated by $\mathrm{N}_{2}$ physisorption and calculated according to the BET method with a Coulter-SA3100 device.

The tricalcic phosphate (TCP) with theoretical formula $\mathrm{Ca}_{3}\left(\mathrm{PO}_{4}\right)_{2}$ was prepared by haste at neutral $\mathrm{pH}$. TCP was formed by mixture of $\mathrm{CaCl}_{2}$ and $\mathrm{Na}_{2} \mathrm{HPO}_{4}$ according the following equation:

$$
\begin{aligned}
3 \mathrm{CaCl}_{2}+2 \mathrm{Na}_{2} \mathrm{HPO}_{4} \rightarrow & \mathrm{Ca}_{3}\left(\mathrm{PO}_{4}\right)_{2}+4 \mathrm{NaCl} \\
& +2 \mathrm{HCl}
\end{aligned}
$$

Some features evaluated for NA and SA apatite studiedare given in the Table 1 (specific surface evaluated by $\mathrm{N}_{2}$-BET method and composition determined by ICP/AES).

Both powder NA, SA and TCP were also analysed by scanning electronic microscopy (SEM) and by FTIR.

\subsection{Sorption experiments}

Sorption experiments were performed in polyethylene bottles containing known amount of sorbent (with ratio apatite/solution optimised at $4 \mathrm{~g} / \mathrm{L}$ ) in the suspension 
Table 1. Typical parameters for NA and SA apatites.

\begin{tabular}{|l|c|c|}
\hline & $\begin{array}{c}\text { Specific Surface } \\
\text { area }\left(\mathbf{m}^{\mathbf{2}} / \mathbf{g}\right)\end{array}$ & Composition \\
\hline NA & 1.5 & $\mathrm{Ca}_{8.92} \mathrm{Na}_{0.32}\left(\mathrm{PO}_{4}\right)_{6}(\mathrm{OH})_{0.7}$ \\
\hline SA & 77 & $\mathrm{Ca}_{8.22} \mathrm{Na}_{0.48}\left(\mathrm{PO}_{4}\right)_{6}(\mathrm{OH})_{1.24}$ \\
\hline
\end{tabular}

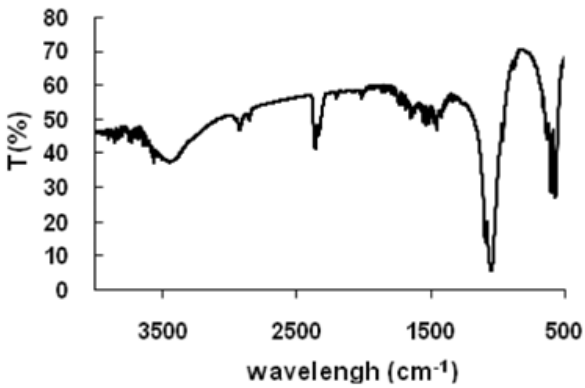

Figure 1. FTIR Specter of NA apatite.

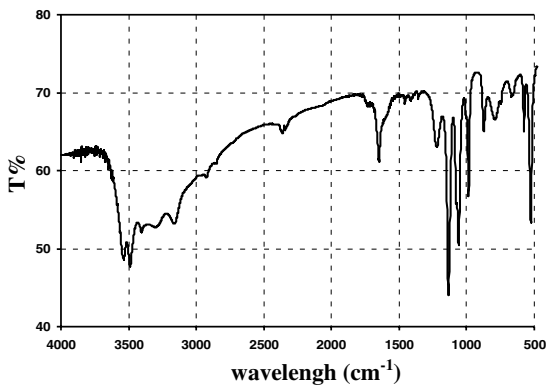

Figure 2. FTIR Specter of SA apatite.

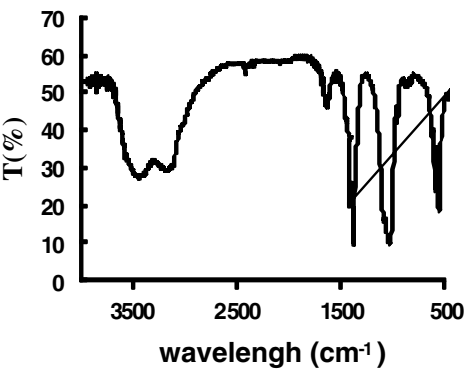

Figure 3. FTIR specter of TCP apatite.

of $50 \mathrm{~mL}$ of cupric or nickel nitrate solutions at range concentration between 20 and $800 \mathrm{mg} / \mathrm{L}$ and constant agitation for periods ranging from 5 to $600 \mathrm{~min}$. The apatite suspensions were shaken at $25^{\circ} \mathrm{C}$ or $40^{\circ} \mathrm{C}$. After time contact, solutions were then filtered on a $0.2 \mu \mathrm{m}$ porosity filter and analyzed for $\mathrm{Cu}$ (or $\mathrm{Ni}$ ) and $\mathrm{Ca}$ by atomic absorption spectroscopy (AAS).

In order to avoid precipitation of nickel or copper hydroxide at $\mathrm{pH}>6$, or apatite dissolution at $\mathrm{pH}<3$, the initial $\mathrm{pH} 4$ and $\mathrm{pH} 5$ were chosen for further experiments $[5,11,15,16]$.

Other experiments were performed by dissolution precipitation of NA, SA and TCP apatites with solution of $\mathrm{Ni}^{2+}$ ions. Dissolution of apatite was conducted at $\mathrm{pH} 2.50 \mathrm{ml}$ of apatite solution was then mixed with $50 \mathrm{ml}$ of metallic solution and stirred for $30 \mathrm{mn}$ at $25^{\circ} \mathrm{C}$. Then $\mathrm{pH}$ solution was adjusted by adding $\mathrm{NaOH}$ solution

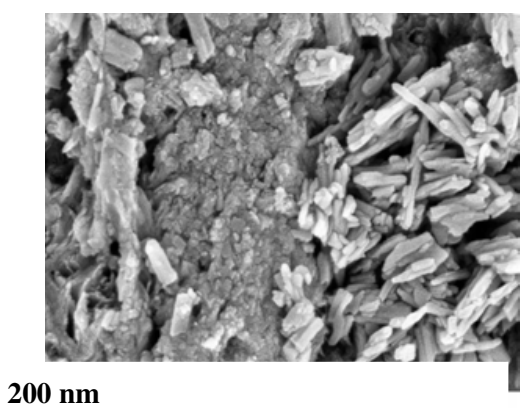

Figure 4. SEM view of NA starting material.

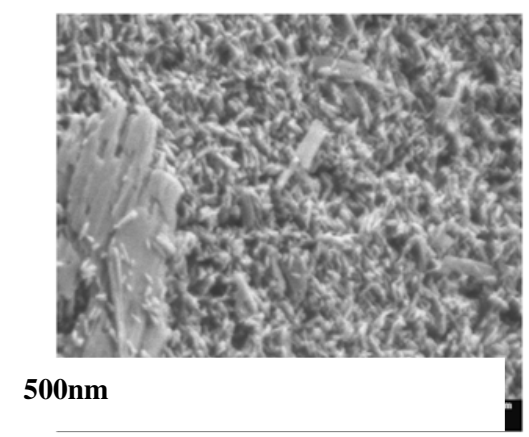

Figure 5. SEM view of SA starting material.

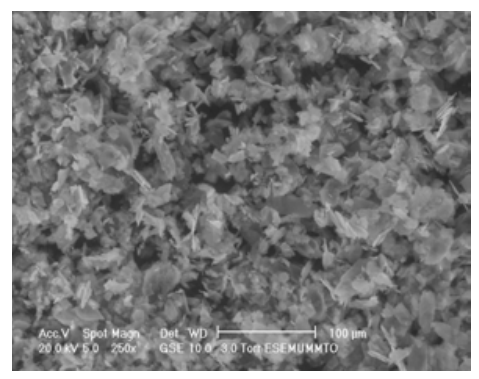

Figure 6. SEM view of TCP apatite.

until phosphate calcium precipitated. After filtration, the solution was analyzed for $\mathrm{Ni}$ byatomic absorption spectroscopy (AAS). Influence of initial amount of NA, SA and TCP on \% removal of $\mathrm{Ni}(\mathrm{II})$ was just studied.

The amount of $\mathrm{Cu}$ (II) or $\mathrm{Ni}(\mathrm{II})$ per unit mass of adsorbent Q in (mg/g) was calculated using Eq. (1):

$$
\mathbf{Q}=\left(\frac{\mathbf{C}_{0}-\mathbf{C}_{\mathbf{f}}}{\mathbf{m}}\right) \mathbf{V}
$$

Where $\mathrm{C}_{0}$ and $\mathrm{C}_{\mathrm{f}}$ are the initial and final metal concentration $(\mathrm{mg} / \mathrm{L}), \mathrm{V}$ is the volume $(\mathrm{L})$ of metal solution used for sorption experiments, and $\mathrm{m}$ is the mass of apatite used $(\mathrm{g})$ respectively.

\section{RESULTS AND DISCUSSION}

\subsection{Results material characterization}

Main results in Table 1 show non stoichiometric hydroxy apatite for NA and SA materials. 


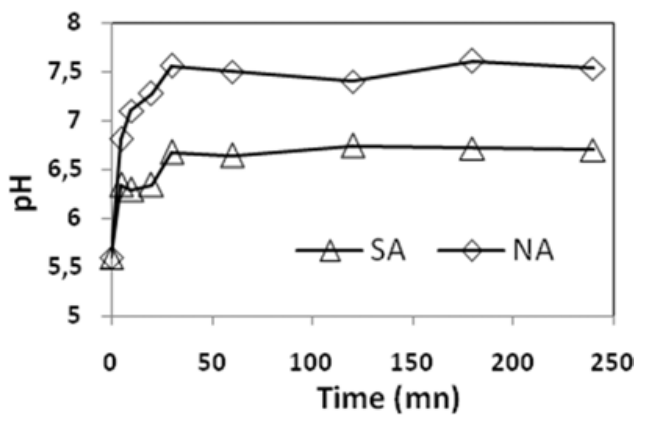

Figure 7. Evolution $\mathrm{pH} \mathrm{Ni}(\mathrm{II})$ solution versus time contact between SA and NA apatite $\left(25^{\circ} \mathrm{C}, 60 \mathrm{ppm}\right.$, pHi 5, $4 \mathrm{~g}$ apatite per L solution).

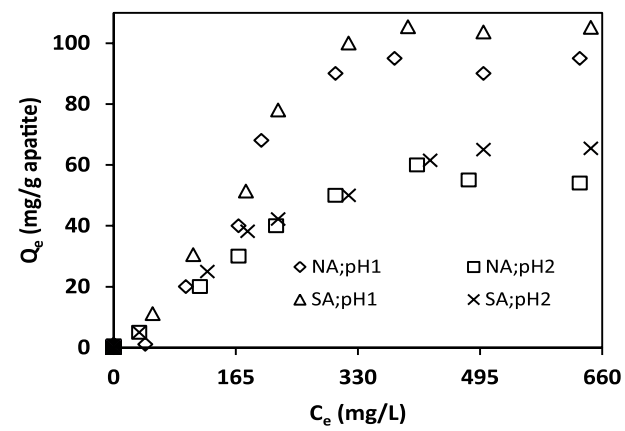

Figure 8. Isotherm sorption of $\mathrm{Cu}$ on $\mathrm{SA}$ and $\mathrm{NA}$ at $25^{\circ} \mathrm{C}$ for $\mathrm{pH} 1=4$ and $\mathrm{pH} 2=5$.

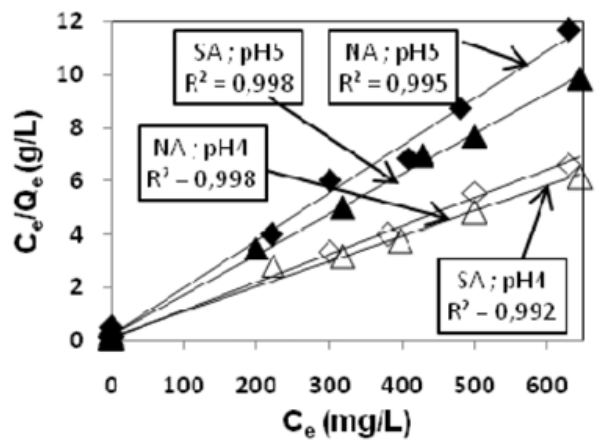

Figure 9. Linear representation of Langmuir model for $\mathrm{Cu}$ sorption.

FTIR specter presented on Figures 1 and 2 show presence of the main peaks of phosphates (601 and $\left.1081 \mathrm{~cm}^{-1}\right)$ and hydroxides $\left(3400 \mathrm{~cm}^{-1}\right)$. But Figure 3 shows alow presence of these peaks characteristic of hydroxy apatite. However Figures 2 and 3 show a presence of carbonate speak around $3400 \mathrm{~cm}^{-1}$. SEM observations, illustrated in Figures 4, 5 and 6, show that NA exhibits a more heterogeneous morphology and strongly anisotropic (Fig. 4). SA appears as platelets with crystals constituted of small elongated particles separated by pores (Fig. 4). About TCP, Figure 6 shows precipitate homogenous structure, that indicates calcium phosphate presence in this material.Variation of $\mathrm{pH}$ solution seen in Figure 7 shows the buffering effect exerted by SA and NA apatites for contact times beyond $50 \mathrm{mn}$. Indeed, the hydroxy apatite and apatites are known for their buffering capacity associated with phosphate groups [17].
Table 2. Values of sorption capacity $\mathrm{Q}_{\mathrm{s}}$ at $\mathrm{pH} 4$ and $\mathrm{T}=25^{\circ} \mathrm{C}$.

\begin{tabular}{|l|c|c|c|c|}
\hline & $\mathbf{C u}^{2+} / \mathbf{N A}$ & $\mathbf{N i}^{2+} / \mathbf{N A}$ & $\mathbf{C u}^{2+} / \mathbf{S A}$ & $\mathbf{N i}^{2+} / \mathbf{S A}$ \\
\hline $\mathrm{Q}_{\mathrm{s}}(\mathrm{mg} / \mathrm{g})$ & 95.24 & 13.64 & 106.38 & 10.94 \\
\hline $\mathrm{Q}_{\mathrm{s}}\left(\mathrm{mg} / \mathrm{m}^{2}\right)$ & 63.49 & 9.09 & 1.38 & 0.14 \\
\hline
\end{tabular}

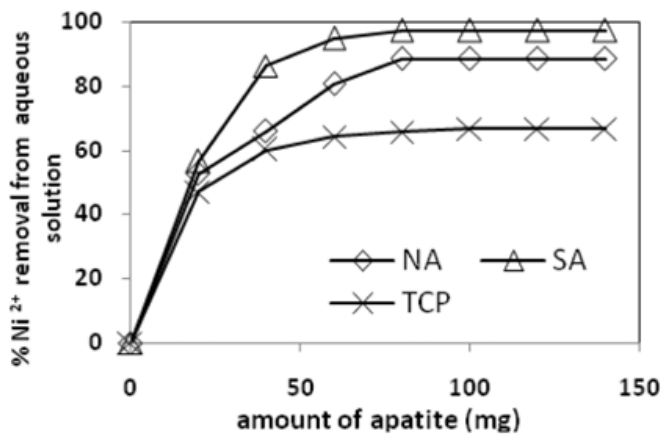

Figure 10. Removal of $\mathrm{Ni}(\mathrm{II})$ in aqueous solution by coprecipitation $\left(25^{\circ} \mathrm{C}, 60 \mathrm{ppm}\right)$.

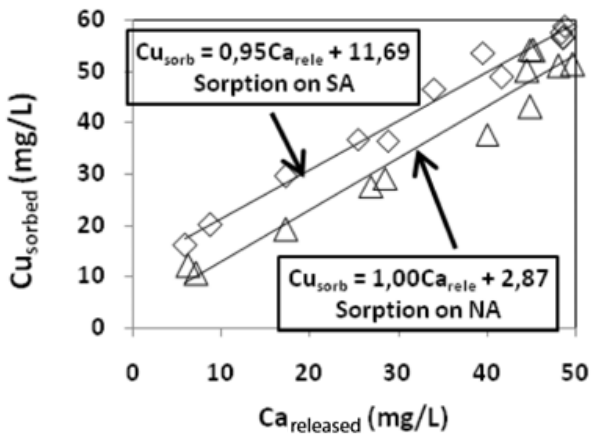

Figure 11. Amount $\mathrm{Cu}(\mathrm{II})$ sorbed on apatite versus $\mathrm{Ca}(\mathrm{II})$ released in solution $\left(\mathrm{T}=25^{\circ} \mathrm{C}\right.$ and $\left.\mathrm{pH}=4\right)$.

\subsection{Isotherm sorption}

Sorption isotherm represents the sorbed concentration $Q_{e}$ (in mg per $g$ of apatite) of the metal after equilibration versus the remaining concentration in the liquid phase $C_{e}$ (in $\mathrm{mg} . \mathrm{L}^{-1}$ ).

Examples of equilibrium sorption of $\mathrm{Cu}(\mathrm{II})$ trends at $\mathrm{pH}$ values of 4 and 5 on both NA and SA are presented in Figure 8 at $25^{\circ} \mathrm{C}$. Similar trends were also observed at $40^{\circ} \mathrm{C}$ and for $\mathrm{Ni}(\mathrm{II})$ adsorption (not shown). Figure 8 show that increasing $\mathrm{pH}$ has negative effects on adsorption capacities of both NA and SA sorbents.

The fit to the linear form of Langmuir model (Figure 9) was examined by calculation of regression values $\left(R^{2}\right)$. The sorption of $\mathrm{Cu}$ and Ni ions on NA and SA follows the Langmuir isotherm model where the uptake occurs on homogeneous surface by monolayer sorption without interaction between sorbed molecules [18]. The best recorded values of sorption capacity $\mathrm{Q}_{\mathrm{s}}$ deduced by fitting experimental data to Langmuir model are given in Table 2 for NA and SA at $\mathrm{pH} 4$ and $25^{\circ} \mathrm{C}$.

Results of dissolution-precipitation between apatite (NA, SA and TCP) and $\mathrm{Ni}^{2+}$ are similar to those shown in Figure 10. We note that removal efficiencies of $\mathrm{Ni}^{2+}$ ions by co precipitation increase as far as amount apatite 


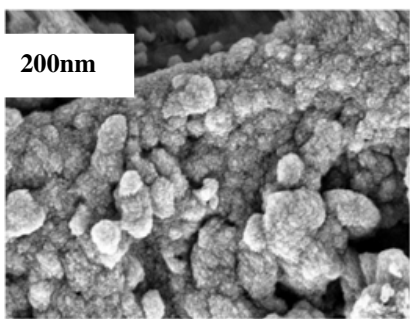

Figure 12. SEM view of NA material after $\mathrm{Cu}$ (II) sorption.

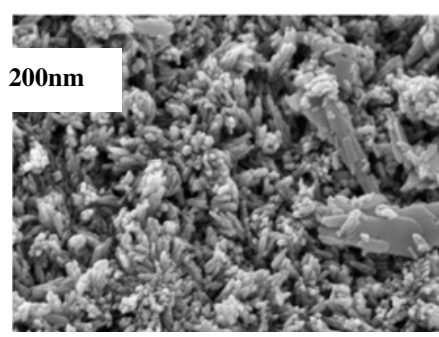

Figure 13. SEM view of SA material after $\mathrm{Cu}(\mathrm{II})$ sorption.

increases until total elimination at about $60 \mathrm{mg}$ of amount apatite. Low efficiency was shown with TCP.

\subsection{Sorption mechanisms}

When sorption of heavy metals occur on hydroxy apatite, an ion exchange process occurs leading to surface fixation of metals as insoluble phosphates against calcium ions release into solution $[5,11,16]$. Thus, amount of $\mathrm{Cu}(\mathrm{II})$ sorbedon NA and SA versus amount of $\mathrm{Ca}$ (II) released was investigated as shown in Figure 11. This figure shows that NA released amount of $\mathrm{Ca}$ (II) roughly similar to amount of uptake $\mathrm{Cu}$ (II) while $\mathrm{SA}$ retained $\mathrm{Cu}$ (II) slightly more than $\mathrm{Ca}(\mathrm{II})$ released to the solution.

Thomson et al. [2], found that synthetic hydroxy apatite had higher capacity than the natural one while carbonated synthetic hydroxy apatite released by an exchange process more calcium ions than non-carbonated ones would have done.

NA and SA were examined by SEM after sorption experiments as shown in Figures 12 and 13. Unlike NA, SA (Fig. 13) appears to be covered more with crystallites of formed precipitates.

\section{CONCLUSION}

This study investigated the capability of natural and synthetic apatites (hydroxy apatites) to sorb $\mathrm{Cu}$ (II) and $\mathrm{Ni}$ (II) ions from aqueous solutions under batch conditions. Several features can be deduced from this study: Copper and nickel ions are well sorbed; sorption is $\mathrm{pH}$ and temperature dependent. Removal of copper or nickel ions from aqueous solutions is efficient on either synthetic or natural Hydroxy apatite but less by co-precipitation of metallic phosphate. The sorption isotherm data fitted well Langmuir-type isotherms with a standard deviation of 0,99 . The sorption mechanism, however, was a function of nature of hydroxy apatite. The $\mathrm{Q}_{\mathrm{s}}$ values obtained lead to practical applications of apatite for waste water decontamination.

\section{References}

[1] F.D. Jr. Tillman, S.L. Baetelt-Hunt, J.A. Smith and G.R. Alther, Evaluation of an organoclay, an organoanthracite blend, clinoptilolite, and hydroxy apatite as sorbents for heavy metal removal from water, Bull. Environ. Contam.Toxicol., 72, pp. 1134-1141 (2004).

[2] B.W. Thomson, C.L. Smith, R.D. Busch, M.D. Siegel and C. Baldwin, Removal of Metals and Radionuclides using Apatite and Other Natural Sorbents, J. Environ. Engin., vol.129, no.6, pp. 492499 (2003).

[3] Gomez del rio, J.A., Morando, P.J., Cicerone DS, Natural materials for treatment of industrial effluents: comparative study of the retention of $\mathrm{Cd}, \mathrm{Zn}$ and $\mathrm{Co}$ by calcite and hydroxy apatite, J. Environ. Manag., 71, pp. 169-177 (2004).

[4] F. Monteil-Rivera and M. Fedoroff, Sorption of inorganic species on apatites from aqueous solutions, Encyclopedia of Surface \& Colloid Science, pp. 1-26 (2002).

[5] F.Fernane, M.O. Mecherri, P. Sharrock, M. Hadioui, H.Lounici and M.Fedoroff, Sorption of cadmium and copper ions on natural and synthetic hydroxylapatite particles, Journal of Materials Characterization, vol. 59, no. 5 (2008) 554-559.

[6] E. Mavropoulos, A.M. Rossi, A.M. Costa, C.A.C. Perez, J.C. Moreira and M. Saldanha, Studies on the mechanisms of lead immobilization by hydroxy apatite, Environ. Sci. Technol., 36, pp. 1625-1629 (2002).

[7] Z. Elouear, R. Ben Amor, J. Bouzid, N. Boujelben, Use of phosphate rock for the removal of $\mathrm{Ni}^{2+}$ from aqueous solutions: kinetic and thermodynamics studies, J. Environ. Eng. ASCE 135 (2009) 259-265.

[8] Freitas J.S., deSalomâo G.C., Gomes M.F.T., Removal of Heavy Metal Ions from Aqueous Solutions by Synthetic Apatites using the Column Ion-Exchange Method., Ecl. Quím. (São Paulo), 25, 19-29 (2000).

[9] Deydier E., Guilet R., Sharrock P, Beneficial use of meat and bone meal combustion residue:an efficient low cost material to remove lead from aqueous effluent, Journal of Hazardous Materials, 101, 55-64 (2003).

[10] Bailliez. S \& Nzihou. A, The kinetics of surface area reduction during isothermal sintering of hydroxy apatite adsorbent, Chem. Eng. J, vol. 98, 141-152 (2004).

[11] F. Fernane, M.O. Mecherri, P. Sharrock, M. Fiallo, R. Sipos, Hydroxyapatite interactions with copper complexes, Journal of Materials Science and Engineering C (2010).

[12] F. Monteil-Rivera, M. Fedoroff, J. Jeanjean, L. Minel and M.G. Barthes, Sorption of selenite $\left(\mathrm{SeO}_{3}^{2-}\right)$ on hydroxy apatite: An Exchange Process, J. of Colloid and Interface Science., 221, pp. 291-300 (2000). 
[13] S. McGrelis, J.N. Serafini, J. Jeanjean, L.J. Pastol, and M. Fedoroff, Influence of the sorption protocol on the uptake of cadmium ions in calcium hydroxy apatite, Sep. Purif. Tech., vol. 24, no.1-2, pp.129 (2001).

[14] Wright J.V. and Conca J.L., Remediation of Groundwater Contaminated with $\mathrm{Zn}, \mathrm{Pb}$ and $\mathrm{Cd}$ using Apatite II, ActaMineralogica-Petrographica, Abstract Series 1, (2003) Szeged.

[15] A. Corami, S. Mignardi, V. Ferrini, Cadmium removal from single- and multimetal $(\mathrm{Cd}+\mathrm{Pb}+$
$\mathrm{Zn}+\mathrm{Cu}$ ) solutions by sorption on hydroxy apatite, J. Colloid Interface Sci. 317 (2008) 402-408.

[16] M. Sljivic, I. Smiciklas, I. Plecas, M. Mitric, The influence of equilibration conditions and hydroxyapatite physico-chemical properties onto retention of $\mathrm{Cu}^{2+}$ ions, Chem. Eng. J. 148 (2009) 80-88.

[17] Yang R.T., Adsorbents, Fundamentals and applications. Wiley Interscience, p. 225 (2003).

[18] Y. Liu, Y. Liu, Biosorption isotherms, kinetics and thermodynamics, Sep. Purif. Technol. 61 (2008) 229-242. 